\title{
MAP kinase inhibitors stimulate $T$ cell and anti-tumor activity in combination with blockade of the PD-L1/PD-1 interaction
}

\author{
Bryan A Irving*, Jeanne Cheung, Yagai Yang, Marina Moskalenka, Marcin Kowanetz, Heather Maecker, Ira Mellman \\ From Society for Immunotherapy of Cancer 28th Annual Meeting \\ National Harbor, MD, USA. 8-10 November 2013
}

Pharmacological inhibition of the MAPK pathway with MEK or BRAF antagonists has proved successful in inducing regression of melanoma tumors bearing the targeted activating mutations. Moreover, antibodies targeting T-cell immune checkpoint inhibitors CTLA-4 or PD-L1/PD-1 have demonstrated the capacity to generate durable responses in patients with multiple cancer types. Thus, combining MAPK pathway-targeted agents with antibodies that enhance anti-tumor immunity represents an increasingly attractive treatment paradigm for cancer. However, little is known about the impact of tumor-targeted agents on immune function as similar signaling pathways drive both T-cell activation and cancer cell proliferation. Accordingly, agents targeting MAPK-dependent tumor growth would be predicted to also inhibit T-cell immunity. Here we show that, unexpectedly, potent suppression of T-cell receptor (TCR) function by MEK inhibition can be largely overcome in the presence of co-stimulation by anti-CD28 in vitro or blockade of the inhibitory PD-L1/PD-1 pathway in $\mathrm{T}$ cells in vivo. The ability of anti-CD28 to override suppression of T-cell activation by MEK inhibitors was dependent on the PI3K/mTOR pathway. Enhanced anti-tumor activity was also observed combining MEK inhibition with PD-L1 blockade, which was likely potentiated by upregulation of tumor MHC Class I expression through inhibition of MEK. Interestingly, inhibitors targeting BRAF V600E mutations actually augmented TCR-driven proliferation in vitro and T-cell function in vivo when combined with a vaccine or blockade of PD-L1 exclusively in the context of a wildtype BRAF background. These data demonstrate that targeting the MAPK pathway can be compatible with or even

Genentech, Inc., South San Francisco, CA, USA enhance $\mathrm{T}$-cell function and provide rationale for combining these inhibitors with immunotherapy in clinical trials.

Published: 7 November 2013

doi:10.1186/2051-1426-1-S1-P79

Cite this article as: Irving et al:: MAP kinase inhibitors stimulate T cell and anti-tumor activity in combination with blockade of the PD-L1/PD-1 interaction. Journal for ImmunoTherapy of Cancer 2013 1(Suppl 1):P79.

Submit your next manuscript to BioMed Central and take full advantage of:

- Convenient online submission

- Thorough peer review

- No space constraints or color figure charges

- Immediate publication on acceptance

- Inclusion in PubMed, CAS, Scopus and Google Scholar

- Research which is freely available for redistribution

(c) 2013 Irving et al; licensee BioMed Central Ltd. This is an Open Access article distributed under the terms of the Creative Commons 